\title{
Henckelia khasiana, a new species of Gesneriaceae from India
}

\author{
Santhosh NAMPY ${ }^{1 *}$, Mannar K. AKHIL ${ }^{2}$, Mohan VISHNU ${ }^{3}$ \\ ${ }^{1,2,3}$ Department of Botany, University of Calicut, Kerala, 673635, India. \\ "Correspondence: santhoshnampy2019@gmail.com \\ 'https://orcid.org/0000-0001-5744-7522, ${ }^{2}$ https://orcid.org/0000-0002-2511-0885 \\ 3https://orcid.org/0000-0001-7702-9184
}

\begin{abstract}
A new species of Henckelia (Gesneriaceae) is here described and illustrated. It is morphologically most similar to $H$. oblongifolia but differs in having lanceolate calyx lobes, two prominent longitudinal flaps on the inner surface of the corolla tube, bilobed stigma and tomentose capsules. A detailed description of the new species with colour photographs, affinities and a comparison with related species is given. Based on the present data, the new species is provisionally assessed as Critically Endangered (CR) according to IUCN Red List Categories and Criteria.
\end{abstract}

Keywords. Conservation status, East Khasi Hills, Mawsynram, Meghalaya, taxonomy.
Resumen. Se describe e ilustra una nueva especie de Henckelia (Gesneriaceae). Esta nueva especie es similar a $H$. oblongifolia, de la que se diferencia por tener lóbulos del cáliz lanceolados, dos láminas longitudinales prominentes en la superficie interna del tubo de la corola, estigma bilobulado y cápsulas tomentosas. Se proporciona una descripción detallada de la nueva especie y fotografías en color de sus principales órganos. Sobre la base de los datos actuales, se evalúa provisionalmente como en Peligro Crítico (CR) de acuerdo con las categorías y criterios de la Lista Roja de la IUCN.

Palabras clave. Estado de conservación, East Khasi Hills, Mawsynram, Meghalaya, taxonomy.

How to cite this article: Nampy S., Akhil M.K., Vishnu M. 2021. Henckelia khasiana, a new species of Gesneriaceae from India. Anales del Jardin Botánico de Madrid 78: e105. https://doi.org/10.3989/ajbm.2570

Title in Spanish: Henckelia khasiana, una nueva especie de Gesneriaceae de la India.

Associate Editor: Alejandro Quintanar. Received: 21 August 2020; accepted: 19 January 2021; published online: 8 June 2021.

\section{INTRODUCTION}

The genus Henckelia Spreng. (Gesneriaceae, Didymocarpoideae) was originally established by Sprengel (1817), but subsequently sunk into the synonymy of Didymocarpus Wall. It was later resurrected by Weber \& Burtt (1998) to include c. 180 species worldwide. Later on, it was remodelled to include only the members of $H$. sect. Henckelia, Chirita sect. Chirita Buch.-Ham. (excluding the species under Damrongia Kerr ex Craib), and the monospecific genus Hemiboeopsis W.T.Wang, excluding the species of $H$. sect. Loxocarpus (R.Br.) A.Weber \& B.L.Burtt, Didymanthus (C.B.Clarke) A.Weber \& B.L.Burtt, Heteroboea (Benth.) A.Weber \& B.L.Burtt and Glossadenia A.Weber \& B.L.Burtt (Weber \& al. 2011; Middleton \& al. 2013). According to recent estimates Henckelia has 71 species distributed from India, Sri Lanka, Myanmar, Nepal, Bhutan, Southern China, Northern Vietnam, Northern Laos and Northern Thailand, of which approximately $50 \%$ are found in India (Manudev \& al. 2012; Middleton \& al. 2013; Sukumaran \& Kumar 2014; Ranasinghe \& al. 2016; Sinha \& Datta 2016; Möller \& al.
2017; Krishna \& Lakshminarasimhan 2018; Sirimongkol \& al. 2019; Bin \& al. 2019; Cai \& al. 2019; Borah \& al. 2019; Kanthraj \& al. 2020; Janeesha \& Nampy 2020; Taram \& al. 2020; Singh \& al. 2020).

The authors while revising the taxonomy of the family Gesneriaceae in India, came across some interesting specimens of Henckelia from Mawsynram in East Khasi Hills district of Meghalaya. Critical examination of the specimens at various herbaria (ARUN, ASSAM, BM, CALI, E, K) and the study of relevant literature revealed that they were morphologically close to $H$. oblongifolia (Roxb.) D.J.Middleton \& Mich.Möller in having caulescent habit, axillary inflorescence with dichotomously branching peduncles, persistent calyx and corolla with yellow lines on the throat; but they also differed in other characters related to the nature and pubescence of leaves, calyx and corolla, fusion of anthers, structure and colour of staminodes, shape of stigma, among others. Differences that will be discussed below led us to describe, on the basis of the mentioned specimens, a new species. 


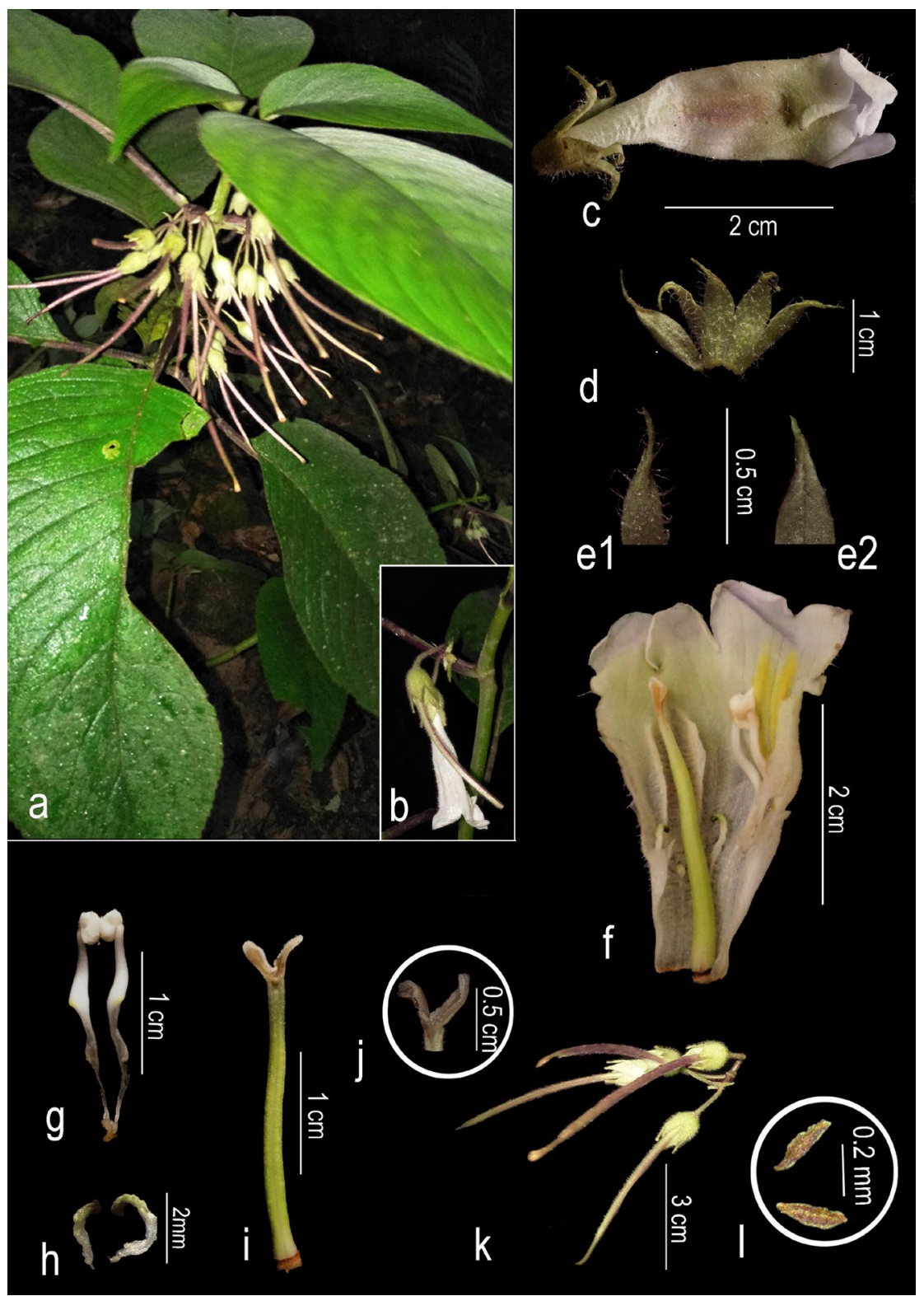

Fig. 1. Henckelia khasiana Nampy \& Akhil sp. nov.: a, habit; b \& c, flower; d, calyx; e, calyx lobe outer (left) and inner (right) surfaces; f, corolla split open showing longitudinal flaps; g, stamens; h, staminodes; i, pistil; j, stigma; k, capsules; l, seeds. [based on Nampy \& Vishnu 156840].

\section{MATERIALS AND METHODS}

The new species is described on the basis of field observations and the examination specimens of Henckelia collected in India, including types at ARUN, ASSAM, BM, CAL, CALI, E, K, MA (acronyms following Thiers, 2020 continuously updated). Herbarium specimens were prepared following the procedure by Forman \& Bridson (1989). Specimen images and species names were all checked from JSTOR Global Plants (http://plants.jstor. org), Tropicos (http://www.tropicos.org) and the International Plant Names Index (http://www.ipni.org). Pro- tologues and relevant literature were examined and the description was prepared following Stearn (1992). Photographs of the plants in the field were taken with an $\alpha-55$ DSLR Camera (Sony, Japan) and those of floral parts with a stemi 508 stereomicroscope (Zeiss, Germany) attached to an Axiocam 105 colour camera. A distribution map was created using the maps from d-maps.com (https://d-maps. com/index.php?lang=en). The provisional conservation threat assessment followed IUCN Categories and Criteria (IUCN 2019). 


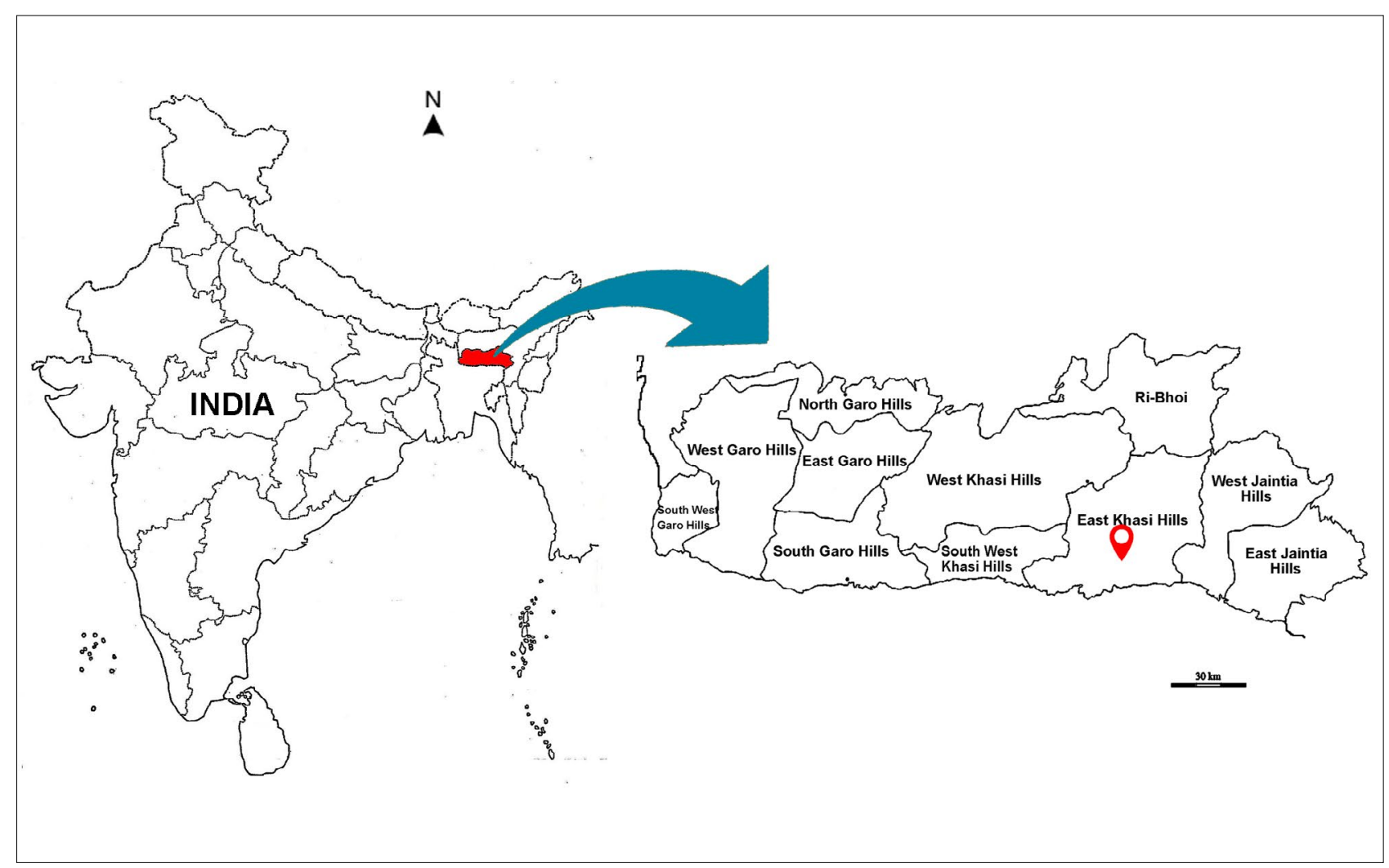

Fig. 2. Map showing the only known locality of Henckelia khasiana Nampy \& Akhil sp. nov. in the Meghalaya state, India.

\section{RESULTS AND DISCUSSION}

Henckelia khasiana Nampy \& Akhil, sp. nov. Type: India. Meghalaya: East Khasi Hills district, Mawsynram, $25^{\circ} 18$ '33”N, 91³4'53”'E, 1366 m, 8 Oct. 2017, Nampy \& Vishnu 156840 (holotype: CALI!; isotypes: MA!, CAL!). Fig. 1.

It is similar to Henckelia oblongifolia (Roxb.) D.J.Middleton \& Mich.Möller because of its general appearance, flower colour and yellow lines on the corolla throat, but differs in the shape of the calyx lobes (lanceolate vs. deltoid), the corolla tube (two prominent longitudinal flaps on the inner side vs. without longitudinal flaps), the stigma (bilobed vs. obdeltoid) and capsules (tomentose vs. pubescent).

Herbs perennial, caulescent. Stems erect, terete, tomentose, up to $1 \mathrm{~m}$ tall; internodes $2.5-6 \mathrm{~cm}$ long. Leaves simple, opposite, anisophyllous; petioles $2-9 \mathrm{~cm}$ long, terete, purple to brown, tomentose. Lamina $12-22 \times 6-10 \mathrm{~cm}$; ovate to widely ovate, dark green above, pale green beneath, pubescent and sparsely gland-dotted above, villous along the nerves and densely gland-dotted beneath; narrowly acute to acuminate at apex; oblique at base, serrulate at margins; lateral veins 8-12 on each side of midrib, arcuate. Cymes usually 2 or rarely 1 from the axil of distal leaves, 2-12 flowered; peduncles $1.2-2.5 \mathrm{~cm}$ long, terete, pubescent. Bracts 2, free, leaf-like, sessile, persistent, 0.3 $0.5 \times 0.1-0.2 \mathrm{~cm}$, lanceolate, acuminate at apex, cuneate at base, ciliate at margins. Pedicels $1.8-3 \mathrm{~cm}$ long, terete, pubescent. Bracteoles 2, free, sessile, persistent, c. $0.6 \mathrm{~cm}$ long, linear, acuminate at apex, cuneate at base, ciliate at margins. Calyx 1.4-1.6 × 0.4-0.6 cm, lobed from above middle, pale green; tube c. $1 \mathrm{~cm}$ long; lobes c. $0.6 \mathrm{~cm}$ long, lanceolate, pilose outside with white hairs, glabrous inside, acuminate at apex, entire at margins. Corolla $4-4.5 \mathrm{~cm}$ long; tube c. $3.5 \mathrm{~cm}$ long, c. $1.5 \mathrm{~cm}$ broad at throat, with two longitudinal flaps along the length of tube on the upper surface; two yellow lines on the throat, densely eglandular hairy outside, sparsely inside; limb 2-lipped, c. $0.5 \times 0.5$ $\mathrm{cm}$, ovate with rounded to obtuse apex. Stamens 2, filaments $0.9-1.2 \mathrm{~cm}$ long, inserted c. $1 \mathrm{~cm}$ from the base of corolla tube, geniculate, white with yellow markings on the knee, sparsely pubescent, attached to the anther at middle of dorsal surface; anthers cream coloured, thecae parallel, lobes c. $0.2 \mathrm{~cm}$ diam., fused face to face, villous near the connectives. Staminodes 3, two large c. $0.5 \mathrm{~cm}$ long, one small c. $0.2 \mathrm{~cm}$ long, curved, free, white but green at apex. Disc ring like; margin undulate, brown. Ovary c. $2 \times 0.2$ 
cm, cylindrical, slightly curved, green, glabrous; style c. $0.8 \mathrm{~cm}$ long, cylindrical, green, glandular pubescent, held between the flaps of upper corolla tube; stigma chiritoid, lower lip bilobed, cream, densely pubescent. Capsules 5-7 $\mathrm{cm}$ long, linear, tomentose, loculicidally dehiscing. Seeds numerous, c. $3 \mathrm{~mm}$ long, flat, fusiform, testa dark brown with a membraneous margin all around.

Distribution and habitat. - Hitherto known only from the type locality (Fig. 2) in tropical evergreen forest at altitudes around $1300 \mathrm{~m}$. It was found in relatively damp, shady areas along rivulets with dense understory.

Phenology. -Flowering and fruiting from September to November.

Etymology. - The specific epithet is derived from the floristically rich Khasi hills in Meghalaya, where the type locality Mawsynram is situated.
Conservation status. - Henckelia khasiana sp. nov. is known only from a single location in the type locality Mawsynram in East Khasi Hills district of Meghalaya. The area of occupancy is assumed to be less than $10 \mathrm{~km}^{2}$. It is under severe threat due to the expansion of highways and other developmental activities in the area. Further surveys in other likely areas are required to estimate the conservation status of the new species. Based on the available data, it is provisionally assessed as "Critically Endangered" (CR) according to the criteria B2ab(iii) of IUCN Red List Categories and Criteria (IUCN 2019).

Notes. -Among the species of Henckelia occurring in India, H. khasiana is most similar to $H$. oblongifolia but differs from the latter in several characters summarized in the diagnosis above and in Table 1.

Table 1. Morphological characters distinguishing Henckelia khasiana Nampy \& Akhil sp. nov. from H. oblongifolia (Roxb.) D.J.Middleton \& Mich. Möller.

\begin{tabular}{|c|c|c|}
\hline Characters & Henckelia khasiana & Henckelia oblongifolia \\
\hline Leaves & $\begin{array}{l}12-22 \times 6-10 \mathrm{~cm} \text {, lance-ovate to widely ovate, serrulate at } \\
\text { margins, upper surface pubescent and sparsely gland-dot- } \\
\text { ted, lower surface villous along the nerves and densely } \\
\text { gland-dotted }\end{array}$ & $\begin{array}{l}6.5-20 \times 3-9.5 \mathrm{~cm} \text {, elliptic to ovate oblong, crenate to crenu- } \\
\text { late at margins, both surfaces tomentose, gland-dotted }\end{array}$ \\
\hline Cymes & Usually 2 , rarely 1 in the axils & Solitary in the axils \\
\hline Calyx & $\begin{array}{l}1.4-1.6 \times 0.4-0.6 \mathrm{~cm} \text {; tube c. } 1 \mathrm{~cm} \text { long; lobes c. } 0.6 \mathrm{~cm} \\
\text { long, lanceolate, pilose out, hairs white }\end{array}$ & $\begin{array}{l}0.8-1 \times 0.7-0.9 \mathrm{~cm} \text {; tube c. } 0.6 \mathrm{~cm} \text { long; lobes c. } 0.3 \mathrm{~cm} \\
\text { long, deltoid, pubescent out, hairs claret coloured }\end{array}$ \\
\hline Corolla & $\begin{array}{l}\text { Eglandular pubescent with two yellow lines on the lower } \\
\text { surface of throat and two longitudinal flaps on the inner } \\
\text { surface distally }\end{array}$ & $\begin{array}{l}\text { Glandular pubescent with two yellow foldings on the lower } \\
\text { surface of throat, longitudinal flaps absent }\end{array}$ \\
\hline Stamens & $\begin{array}{l}\text { Filaments } 0.9-1.2 \mathrm{~cm} \text { long, geniculate, white with yellow } \\
\text { markings on the knee, sparsely pubescent, attached to the } \\
\text { anther on middle of dorsal surface; anthers villous near the } \\
\text { connectives, theca parallel, lobes fused face to face }\end{array}$ & $\begin{array}{l}\text { Filaments } 1-1.3 \mathrm{~cm} \text { long, fusiform, white, glandular pubes- } \\
\text { cent, attached to the anther on entire dorsal surface; anthers } \\
\text { glabrous, theca divergent, lobes fused apically }\end{array}$ \\
\hline Staminodes & Curved, white but green at apex & Straight, white in colour \\
\hline Stigma lower lip & Bilobed & Obdeltoid, emarginated \\
\hline Style & Glandular pubescent, green & Sparsely pilose, white \\
\hline Ovary & Glabrous, green coloured & $\begin{array}{l}\text { Densely pubescent, gland dotted, white, covered by claret } \\
\text { coloured hairs }\end{array}$ \\
\hline Capsules & Tomentose & Pubescent \\
\hline
\end{tabular}




\section{ACKNOWLEDGEMENTS}

We are thankful to the head of the Department of Botany, University of Calicut, Kerala for facilities; officials of Meghalaya Forest Department for permission to undertake field trips; SERB New Delhi for funding (EMR/2016/007346 dated 01/11/2018) and to Dr. Michael Möller, RBG Edinburgh for initial discussion.

\section{REFERENCES}

Bin Y., Ding H.B., Fu K.C., Yuan Y.K., Yang H.Y., Jian W.L., Zhang L.X. \& Tan Y.H. 2019. Four new species of Gesneriaceae from Yunnan, Southwest China. PhytoKeys 130: 183-203.

Borah D., Taram M., Joe A. \& Neelamkavil S.V. 2019. Henckelia collegii- sancti-thomasii: a new species of Henckelia (Gesneriaceae) from Northeastern India. Phytotaxa 415: 247-251.

Cai L., Liu D.T., Zhang P. \& Dao Z.L. 2019. Two new species of Henckelia (Gesneriaceae) from South eastern Yunnan, China. In: Cai J., Yu W-B., Zhang T. \& Li D-Z. (ed.), Revealing of the plant diversity in China's biodiversity hotspots. PhytoKeys 130: 151-160.

Forman L. \& Bridson D. 1989. The herbarium handbook. Kew: Royal Botanic Garden.

Janeesha A.P. \& Nampy S. 2020. A taxonomic revision of Henckelia (Gesneriaceae) in South India with a new species, one new combination and seven lectotypifications. Rheedea 30: 48-95.

Kanthraj A.S., Rana T.S. \& Nair K.N. 2020. Henckelia umbellata (Gesneriaceae), a new species from the eastern Himalaya of India. Rheedea 30: 143-149.

Krishna G. \& Lakshminarasimhan P. 2018. A new species of Henckelia (Gesneriaceae) from Arunachal Pradesh, India. Taiwania 63: 397-401.

Manudev K.M., Weber A. \& Nampy S. 2012. Henckelia pradeepiana a new species of Gesneriaceae from southern Western Ghats, India. Rheedea 22: 119-123.

Middleton D.J., Weber A., Yao T.L., Sontag S. \& Möller M. 2013. The current status of the species hither to assigned to Henckelia (Gesneriaceae). Edinburgh Journal of Botany 70: 385-403.
Möller M., Nampy S., Janeesha A.P. \& Weber A. 2017. The Gesneriaceae of India: Consequences of updated generic concepts and new family classification. Rheedea 27: 23-41.

IUCN 2019. Guidelines for using the IUCN Red List Categories and Criteria, Version 14. - Prepared by the Standards and Petitions Committee.

Ranasinghe S., Milne R., Jayasekara R., Rubasinghe S. \& Möller M. 2016. Henckelia wijesundarae (Gesneriaceae), a new endemic species from Sri Lanka, and lectotypification of Chirita walkerae and C. walkerae var. parviflora. Willdenowia 46: 213-224.

Singh R.K., Arigela R.K., Borah D. \& Taram M. 2020. Henckelia collegiisancti-thomasii (Gesneriaceae), a new synonym of narrow endemic species H. hookeri of Northeast India. NeBIO 11: 205-207.

Sinha B.K. \& Datta S. 2016. Taxonomic account of the family Gesneriaceae in northeast India. Nelumbo 58: 1-43.

Sirimongkol S., Parnel J.A.N., Hodkinson T.R., Middleton D.J. \& Puglisi C. 2019. Five new species of Henckelia (Gesneriaceae) from Myanmar and Thailand. Thai Forest Bulletin (Botany) 47: 38-54.

Sprengel K. 1817. Fam. XXIX. Perfonaten. Anleitung Zur Kenntniss der Gewächse, Zweite 2: 390-406.

Stearn W.T. 1992. Botanical Latin: History, Grammar, Syntax, Terminology and Vocabulary ed. 4. Timber Press, Portland.

Sukumaran E. \& Kumar S. 2014. A new combination in Henckelia (Gesneriaceae). Polish Botanical Journal 59: 149.

Taram M., Borah D., Taku O. \& Tag H. 2020. Henckelia siangensis (Gesneriaceae): a remarkable new species from Northeast India. PhytoKeys 160: 1-6.

Thiers B. 2020 [continuously updated]. Index Herbariorum: a global directory of public Herbaria and associated staff. New York Botanical Garden's Virtual Herbarium, New York. http://sweetgum.nybg.org/science/ ih/ [accessed 25 Jun 2020].

Weber A. \& Burtt B.L. 1998. Remodelling of Didymocarpus and associated genera (Gesneriaceae). Beiträge zur Biologie der Pflanzen 70: 293-363.

Weber A., Middleton D.J., Forrest A., Kiew R., Lim C.L., Rafidah A.R., Yao T.L. \& Möller M. 2011. Molecular systematics and remodelling of Chirita and associated genera (Gesneriaceae). Taxon 60: 767-790. 